\title{
ENFORCING WAGERING CONTRACTS
}

\author{
Sid Wellik
}

In Lipkin Gorman, Lord Goff stated that placing a bet is in law a gift and that when winnings are paid a gift is received. New Zealand legislation excludes contractual enforcement of wagering transactions, except in licensed casinos. This paper explores whether Lord Goff's analysis and current New Zealand legislation are an appropriate legal state of affairs for gaming transactions.

\section{INTRODUCTION}

An overall review of gaming is desirable so that the gaming industry can develop in a way which better matches the needs and expectations of the New Zealand public and is cognisant of the social and economic factors involved.

These are the words of the Minister of Internal Affairs in the Foreword to Review of Gaming -- A Discussion Document $1995 .^{1}$ The need to meet the public's expectations is fundamental to the review. Yet at law, a gaming transaction is a mere gift. ${ }^{2}$ This is an obvious example of how the law does not meet public expectations.

A variety of issues are being considered under the review, ${ }^{3}$ for example problem gambling, 0900 telephone games and internet gambling. One issue that remains unaddressed is whether gaming contracts should be enforceable. Currently, legislation

* This is an edited version of a paper submitted in fulfilment of the VUW LLB (Hons) legal writing requirements.

1 Department of Internal Affairs (Wellington, August 1995) iii.

2 See Lipkin Gorman v Karpnale Ltd [1991] 2 AC 548, 560 (HL), per Templeman LJ [Lipkin Gorman (HL)].

3 The Department of Internal Affairs is currently undertaking a review of gaming law in New Zealand. Recently, it has published nine papers regarding various aspects of the gaming industry. Many legislative reforms are being considered and some are in the Gaming Law Reform Bill (No 250 of 1998) currently before Parliament. 
restricts enforceability of both wagering and gaming contracts. ${ }^{4}$ This legislative obstacle makes rights of redress for failed gaming transactions uncertain. ${ }^{5}$ If the statutory restrictions were removed, participants in gaming transactions would have established and certain rights of redress in contract.

The reason the current legislation contains this obstacle is difficult to ascertain. Historically at common law, both wagering and gaming contracts have been enforceable. ${ }^{6}$ As will be shown, there are no reasons at common law why gaming contracts should be void or illegal, and the current Departmental policy would be supported by contractual enforceability. This paper discusses these issues and proposes that the legislative barriers against enforcement should be removed for all gaming contracts ${ }^{7}$ where monetary consideration has been paid. ${ }^{8}$

The colloquial term 'gambling' is a general term referring to gaming and wagering. The individual terms 'wagering' and 'gaming' have separate legal meanings. Although neither term is defined in legislation, case law has established working definitions.

A wager is defined as: ${ }^{9}$

4 The one exception is the enforceability of gaming contracts within a licensed casino: the Casino Control Act 1990, s 6.

5 The availability of redress outside a contractual claim, for example via statutory regulations, statutory duties or administrative remedies, is not addressed in this paper. Only housie and the activities of the Lotteries Commission have statutory regulations. Those regulatory remedies are unclear and in some circumstances discretionary. A remedy for breach of statutory duty or an administrative remedy is also without precedent and therefore uncertain.

6 See R A Moodie Wagering and Gaming Contracts in New Zealand (Unpublished PhD Thesis, Victoria University of Wellington, 1976) [Moodie] 1.03, 1.04; in 18th century England wagering contracts were legal, and only excessive gaming contracts were illegal. See also Hyams $v$ Stuart King [1908] 2 KB 696, 712, per Fletcher Moulton LJ; see also Da Costa v Jones (1778) 2 Cowp 729, per Mansfield LJ.

7 This paper only addresses those gaming activities which legislation regulates. This paper does not discuss the enforceability of 'strict wagering' contracts. Strict wagers raise serious public policy concerns with regard to contacts of loan for gambling, issues of problem gambling, as well as possible issues under the Contracts Credit Act 1981. Section 128(1)(b) of the Gaming and Lotteries Act 1997 excludes the enforceability of such loans for those reasons. Regarding issues of social impact, see Department of Internal Affairs The Social Impact of Gaming in New Zealand (Wellington, November 1995) 7. Regarding issues under the Credit Contracts Act 1981, see J F Burrows, Jeremy Finn, and Stephen M D Todd The Law of Contract in New Zealand (Butterworths, Wellington, 1997) 385 [The Law of Contract in New Zealand].

8 This paper's analysis will be restricted to transactions where there is an exchange of money. Although gaming transactions do occur through a mere exchange of promises, such transactions raise public policy concerns; see above $\mathrm{n} 7$.

9 Carlill v Carbolic Smoke Ball Company [1892] 2 QB 484, 490, per Hawking J. 
...two persons, professing to hold opposite views touching the issue of a future uncertain event, ${ }^{10}$ mutually agree that, dependent upon the determination of that event, one shall win from the other, and that other shall pay or hand over to him, a sum of money or other stake.

Wagering, therefore, is a general definition where two parties take opposite views on an event, and on the outcome one party wins the stake that the other party has wagered. ${ }^{11}$ Traditionally, the bet is paid only after the event. The definition of gaming is similar to that of wagering. ${ }^{12}$ However, gaming is a subset of wagering; it is a specific type of wagering. Gaming is most accurately defined as a wager relating to a game. ${ }^{13}$ Wagering which cannot also be defined as gaming is more accurately defined as a 'strict wager.' Those participating in gaming activities will be referred to, in this paper, as 'gaming consumers. ${ }^{14}$

\section{NEW ZEALAND LEGISLATION}

Currently in New Zealand there are several Acts that regulate the gaming industry. ${ }^{15}$ Three distinct types of gaming are each regulated by their own statute. They are horse

10 There are other types of contracts which pertain to some "future uncertain event" which are not wagering or gaming contracts. Insurance contracts are one example of another type of aleatory contract. What distinguishes wagering and gaming contracts is that the winning of the stake or prize "is the only interest that either party has in the contract...[The] presence or absence of an interest in the contract [is what] distinguishes many legitimate agreements from wagering contracts." Insurance contracts, as a general rule, have an insurable interest as well: The Law of Contract in New Zealand, above n 7, 384 .

11 No money is required to pass. This not only raises the concerns in above $\mathrm{n} 7$, but also raises concerns about, at the time of the wager, whether each participant views the transaction as a debt of honour rather than a legally enforceable transaction.

12 Weathered $v$ Fitzgibbon [1925] NZLR 331 (SC) addressed issues regarding the Gaming Act 1908 (NZ). Justice Salmond defined gaming (also referred to as gambling in its legal context) at 333 as "...playing at any game for stakes--that is to say, for money or money's worth, to be obtained by the winner from the loser...It makes no difference in this respect whether the game is one of chance or one of skill." See also Lockwood v Cooper [1903] 2 KB 428, 431.

13 See Hyams $v$ Stuart King [1908] 2 KB 696, 714, per Fletcher Moulton LJ "...that form of wagering ...generally known as gaming" [Hyams].

14 The term 'consumer' acknowledges the commercial nature of the participant's action, which deserves protection. The New Zealand Lotteries Commission has referred to gambling services as 'gaming and gambling products": Responsible Gaming: A Community Benefit Model (Wellington, November 1995) 9.

15 It is not the purpose of this paper to discuss the tax legislation surrounding gaming, but it should be noted that three separate Acts apply to the taxation of gaming: the Gaming Duties Act 1971, the Goods and Services Tax Act 1985, and the Income Tax Act 1994. 
racing, casinos, and gaming and lotteries. Each statute has its own distinct legislative regime.

\section{A Gaming and Lotteries: Charitable Gaming}

The Gaming and Lotteries Act 1977 (GLA) covers all gaming activities, except for horse racing and casinos which are regulated by their own statutes. It is a comprehensive Act providing general rules.

The common link between all activities under this Act, and the Act's distinguishing feature, is that the proceeds must be directed towards a charitable or community purpose. Commercial gain is prohibited under the Act. ${ }^{16}$ "Gaming" activities within the Act are games of chance, instant games, prize competitions and lotteries. Sales promotions that do not generate profit must also adhere to certain regulations.

Part IX of the Act, enforcement by civil proceedings, relates to the enforceability of wagering and gaming contracts. The Act distinguishes between the effects of wagering and gaming contracts, ${ }^{17}$ although the Act does not define either wagering or gaming. Historical case law definitions, therefore, raise particular issues regarding statutory interpretation.

Part IX includes sections 126 - 132. Section 126 codifies the laws relating to both gaming and wagering, ${ }^{18}$ and it states that no contract, or term of a contract, shall be ineffectual, unenforceable or illegal by reason only that it relates to wagering or gaming. ${ }^{19}$ It shall be so only by reference to the other provisions within Part IX. ${ }^{20}$

Section 128 is the general section, referring to wagering, and therefore gaming as well. ${ }^{21}$ Section 128 states that certain contracts shall be unenforceable. These include wagering contracts, ${ }^{22}$ contracts of loan for the purposes of wagering contracts, and

16 See the Long Title of the Gaming and Lotteries Act 1977.

17 Gaming contracts being those with regard to games of chance, instant games, prize competitions and lotteries: the Gaming and Lotteries Act 1977, s 129.

18 Section 126(1) of the Gaming and Lotteries Act 1977.

19 Section 126(2) of the Gaming and Lotteries Act 1977.

20 This Part of the Act supports the view that, although Parliament wishes to regulate gaming and wagering, it does not view either as immoral or invalid in substance.

21 See the Introduction of this paper regarding common law definitions.

22 Section 128(1)(a) of the Gaming and Lotteries Act 1977. 
contracts of agency in respect of wagering contracts. ${ }^{23}$ Contracts which try to mitigate the purpose or consequences of any of those contracts are also unenforceable. ${ }^{24}$

Section 128 also states that section 6 of the Illegal Contracts Act 1970 (ICA) shall apply to the aforementioned contracts. ${ }^{25}$ However, there is no jurisdiction under section 7 of ICA to grant relief to those contracts. ${ }^{26}$ The section bars any proceedings to enforce any of the listed contracts. ${ }^{27}$ Section 128 is clear: there is no relief available in civil proceedings for wagering contracts under the GLA.

Further section 128 affects section $129 .{ }^{28}$ Section 129(1)(a) reads: "Every contract (not being a wagering contract) relating to the participation of any person in any game of chance or instant game or prize competition or lottery..." 29 shall be an illegal contract for the purposes of the ICA. ${ }^{30}$ This section also states that any of these contracts that pertain to loans ${ }^{31}$ and agency ${ }^{32}$ shall be illegal for the purposes of the ICA.

Contracts under section 129 are illegal, however the section allows for discretionary relief under section 7 of the ICA, as it is not specifically excluded. In contrast, as noted earlier, discretionary relief is excluded for contracts under section $128 .{ }^{33}$ The interpretation is problematic because the Act refers to gaming and wagering contracts as two distinct categories, rather than gaming being a subset of wagering.

23 Section 128(1)(c) of the Gaming and Lotteries Act 1977.

24 Section 128(1)(d) of the Gaming and Lotteries Act 1977.

25 Section 128(2) of the Gaming and Lotteries Act 1977.

26 Section 128(3) of the Gaming and Lotteries Act 1977.

27 Section 128(4) of the Gaming and Lotteries Act 1977.

28 Section 129(2) of the Gaming and Lotteries Act 1977.

29 The Act gives no definitions of 'wagering' or 'gaming.' As noted earlier, the common law position defines gaming as a subset of wagering. This being the case, statutory interpretation and application of s 129 is problematic, for all gaming contracts are wagering contracts by definition. See also below $\mathrm{n} 33$. Section 129(1) of the Gaming and Lotteries Act 1977.

31 Section 129(1)(b) of the Gaming and Lotteries Act 1977.

32 Section 129(1)(c) of the Gaming and Lotteries Act 1977.

33 If taken on the common law definitions, these gaming contracts, being wagering contracts, would be excluded from remedies under the Illegal Contracts Act. Yet s 129 clearly states: "Every contract (not being a wagering contract)..."This lack of clarity of definition is problematic for statutory interpretation. 


\section{B Horseracing: The Racing Industry}

New Zealanders have always had a special appreciation for horseracing. The Racing Act 1971 (RA) recognises that fact by providing special legislation for racing, which includes horseracing, galloping, greyhound racing and harness racing. This Act not only regulates betting in the industry, but addresses all matters concerned with racing. All profits from the activities under this Act are directed to the promotion and maintenance of the racing industry.

Rights of redress to gaming consumers are covered in the Act. Section 41 states that a bet will be refunded if a horse is withdrawn from a race or if there is a problem with the starting equipment. Section 88 places an obligation on the TAB to pay dividends. However section 103 is entitled "Money Bet Not Recoverable." It reads:

No action shall be brought or maintained in any Court against the Industry Board, the Board, or any racing club for the recovery of any money won, lost, or bet under any form or type of betting authorised by or pursuant to this Act.

There is no allowance for a grievance regarding a gambling transaction. The section is explicit. ${ }^{34}$ The racing industry does have its own Review Board, but section 99ZK states that there shall be no appeals to any Appeals Tribunal regarding placings or stakes on the day of the race. The Act addresses procedures regarding racing and the amount of the dividends. It is not within the scope of the Act to appeal a decision by the TAB not to pay winnings.

\section{Licensed Casinos: Commercial Profit}

The passing of the Casino Control Act 1990 (CCA) marks a significant change in the attitude of Parliament towards gaming. This Act allows for the establishment of casinos for commercial profit. Such profit is allowed within the purposes of paragraph (b) of the long title of the Act which reads: "To promote the development of licensed casinos in a manner consistent with the promotion of tourism, employment, and economic development generally."

Section 6 of the CCA covers all matters concerning the application of the GLA to the CCA. This specifically addresses Part IX of the GLA and contractual enforceability. Section $6(1)$ is an exception to all other gaming legislation. It states "[n]otwithstanding

34 An administrative remedy may be available if it were established that the TAB had a statutory duty to pay the gambling consumer. By not paying the winnings the TAB would be acting illegally. The courts could refuse to apply the privative clause of s 103, based upon the reasoning that privative clauses cannot save errors of law: see Bulk Gas Users Group v Attorney-General [1983] NZLR 129 (CA) and New Zealand Rail Ltd v Employment Court [1995] 3 NZLR 179 (CA). 
anything in the Gaming and Lotteries Act 1977 or any other rule of law, wagering contracts relating to gaming in licensed casinos shall be enforceable at law." 35 Parliament clearly created an exception for the enforcement of wagering contracts relating to gaming when the purpose is for commercial profit. However there is no detailed discussion in the records as to why this is an exception. ${ }^{36}$

Notwithstanding that exception, Part IX of the GLA applies in respect of gaming in licensed casinos, ${ }^{37}$ and no other part of the GLA applies. ${ }^{38}$ Therefore matters such as loans for gaming and agency relationships are covered by the GLA. A simple contractual remedy is available for a gaming consumer in a licensed casino.

However there are statutory interpretation problems. Is section 128 and/or section 129 of the GLA affected by section 6 of the CCA? A broad view would hold that both sections 128 and 129 of the GLA are being referred to; all gaming contracts are enforceable, except those regarding loans and agency relationships. A narrow view would hold that only section 128 of the GLA is affected, as section 6 of the CCA refers specifically to 'wagering contracts' relating to gaming. The interpretation of section 6 of the CCA would affect the applicability of the ICA. It is not clear which sections of the GLA are being referred to.

\section{GAMING CONTRACTS AT COMMON LAW}

The statutory barrier to enforcement is clear. Therefore it is central to the discussion to know whether gaming transactions can be valid contracts at common law. If so, contractual enforceability would allow certainty for rights of redress.

35 This strengthens the view that the interpretation of s 129 of the Gaming and Lotteries Act 1977 is problematic. See above n 29 and 33. If the Casino Control Act 1990 recognises that gaming contracts are a subset of wagering, then how can s 129 of the GLA, which refers to only gaming contracts which could not be wagering contracts, be properly interpreted?

36 This is a clear departure from other New Zealand legislation and the English law, under which the Gaming Act 1845 makes all wagering and gaming contracts void. The English Act applies to casinos also: see Lipkin Gorman (HL) above $\mathrm{n}$ 2. There is no reference with regard to this departure in the New Zealand Parliamentary Debates, the Appendix to the Journals of the House of Representatives, nor in The Report of the Committee of Enquiry into the Establishment of Casinos.

37 Section 6(2) of the Casino Control Act 1990.

38 Section 6(3) of the Casino Control Act 1990. 


\section{A Contract Formation}

\section{Phenomenon of agreement}

Gaming contracts clearly fit within the established legal rubric of the phenomenon of agreement. This can be shown by a simple example. Someone purchases a lottery ticket or a scratch and win ticket. First there is an invitation to treat by the vendor. The purchaser hands over the money, which is the offer, and the vendor accepts the money and hands over a ticket. Acceptance occurs with the giving of the ticket. This analysis follows Pharmaceutical Society of Great Britain v Boots Cash Chemists (Southern) LTD. ${ }^{39}$ No issue exists with regard to the phenomenon of agreement.

\section{Intent to create legal relations}

Both parties intend to create a legal relationship within a normal consumer context. This legal relationship is presupposed between the gaming consumer and a commercial profit-making establishment, for example a casino. Likewise when a gaming consumer purchases a raffle ticket from a local charity, for example from a church, a right of redress is presumed if a prize is not allocated. The expectation of the consumer is consistent. Arguments that the gaming consumer is simply making a gift become strained when any gaming consumer seeks enforcement of the agreement.

\section{Consideration}

When analysing casino transactions with regard to unjust enrichment, the House of Lords held in Lipkin Gorman ${ }^{40}$ that valuable consideration was not present. Without consideration being present, the enrichment of the defendant was unjust. This analysis raises concerns for the issue of consideration within contractual relationships.

\section{(a) Current common law status}

In Lipkin Gorman (HL) there was a claim in restitution for stolen money that was subsequently bet in a casino. The issue was whether the original owner of the money (the party from whom it was stolen) could recover it from the casino. One aspect of the reasoning dealt with the issue of consideration and the effect of section 18 of the Gaming Act 1845 (UK). One form of analysis in the decision was whether or not there was valuable consideration given by the casino to the gaming consumer, in exchange for the money bet. The 1845 Act states that all gaming and wagering contracts are null and void.

39 [1952] 2 QB 795.

40 See above $\mathrm{n} 2$. 
The Court of Appeal ${ }^{41}$ held that there was consideration. Lord Parker gave two reasons. First, he employed a two contract analysis. In the first contract money was exchanged for chips, the latter being viewed as the source of consideration. The second contract was the wagering of chips. This wagering contract was, therefore, separate from the issue of consideration. ${ }^{42}$ Second, the chance of winning and the chance of being paid were held to be valid consideration, despite the contracts being void under the 1845 Act. ${ }^{43}$ Lord May agreed with the first of those reasons. ${ }^{44}$

In the House of Lords, Lord Templeman held that although the club received the money "fairly and honestly", it did not do so "upon valuable and bona fide consideration." $45 \mathrm{He}$ also held that the giving of chips in exchange for the money was part of a single transaction, and that chips were not valuable consideration. ${ }^{46}$ Parts of both Lord Templeman's and Lord Goff's analyses were based on the fact that the gaming contracts were void under the 1845 Act. For Lord Templeman this meant that the defendant could not rely on those void contracts to retain the money. Lord Goff's analysis was different: ${ }^{47}$

The contract of gaming was void; in other words, it was binding in honour only. Cass (the defendant)...had no legal right to claim them (winnings). He simply had a confident expectation...But it does not follow that, when Cass placed the bet, he received anything the law recognises as valuable consideration...Even when a winning bet has been paid, the gambler does not receive valuable consideration for his money. All that he receives is, in law, a gift from the club.

However, with respect, Lord Goff gets the reasoning backwards. It does not follow, as he suggests, that because the transaction is unenforceable there is no consideration. For as Lord Goff points out if the club did not pay, "...it would very soon go out of business."48 The gaming contracts were void, however there was consideration given; ${ }^{49}$ it is simply

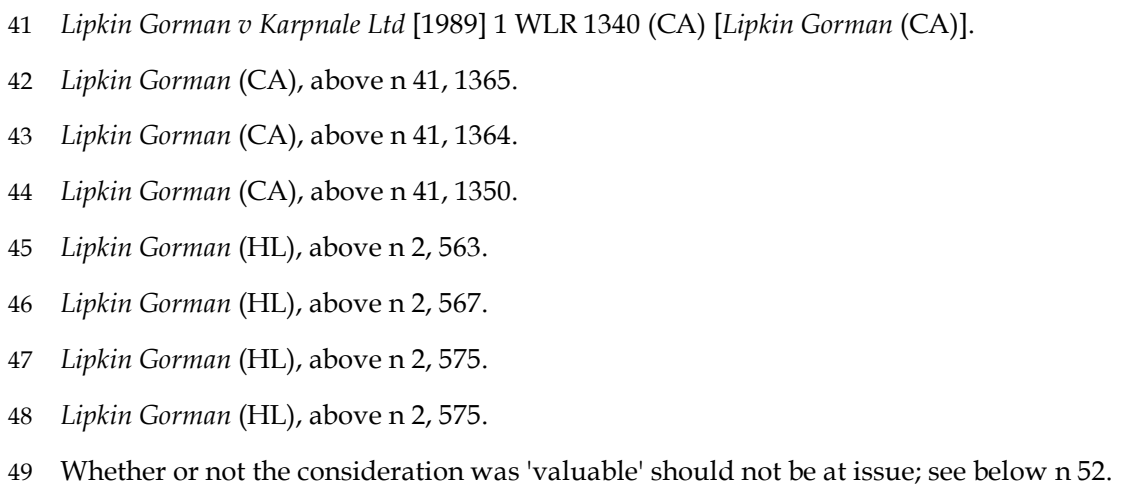


that the contract is unenforceable. The issue of contract formation is an issue separate from contractual remedies. ${ }^{50}$

\section{(b) Common law arguments for validity of consideration}

Historically, no issue arose over the presence of consideration for wagering (including gaming) contracts. The statement of Lord Justice Fletcher Moulton in Hyams $v$ Stuart King is relevant: "By common law wagers were not illegal, and the nature of a wager is such that from the point of view of jurisprudence there is ample consideration for a valid contract." 51

Both reasons by Lord Justice Parker in Lipkin Gorman (CA) are also valid. Lord Justice Parker's first reason, that in a casino situation, chips are given in exchange for the money, shows consideration. If the chips are not viewed as 'valuable' consideration, this is not consistent with the traditional views of consideration. Consideration is an exchange of promises; "[it] has been settled for well over 300 years that the courts will not inquire into the 'adequacy of consideration." ${ }^{22}$ Adequacy is not an issue with regard to consideration, as long as there is sufficiency.

Lord Justice Parker's second reason is that there is a definite benefit to the gaming consumer and a detriment to the institution taking the bet: the gaming consumer has a chance of winning and of being paid. The gaming consumer is purchasing an opportunity to win. The gaming consumer is not giving a gift, nor expecting nothing in return for his or her money. Also, there exists entertainment value in the transaction. These benefits are always present in gaming transactions, so consideration is clearly present.

In New Zealand, the GLA defines the statutory gaming activities ${ }^{53}$ in section 2. As part of each definition, consideration, direct or indirect, must be paid to participate. Such definitions expressly state that consideration is present in these gaming activities.

As there is no common law reason to restrict the valid formation of gaming contracts, the next issue is whether such agreements are illegal or void contracts.

50 See s 4 of the Limitations Act 1950: contractual claims are deemed to be unenforceable after 6 years, but such does not affect their legality or validity.

51 Hyams above n $12,712$.

52 The Law of Contract in New Zealand above n 7, 102.

53 The games listed in the statute are games of chance, instant games, prize competitions and lotteries. 


\section{B Illegal and Void}

Section 126 of the GLA makes a clear statement. It says "no term of a contract shall be held to be ineffectual, unenforceable, or illegal by reason only that it relates to wagering or gaming, otherwise than by virtue of ... [these] ${ }^{54}$ provisions." This suggests that without this statutory obstacle, gaming contracts would not be illegal or invalid at common law. If gaming contracts are neither illegal or void at common law, the question must be asked 'why does the statutory exclusion exist?'

\section{Illegal at common law}

Section 3 of the ICA states that contracts which are illegal at common law come under the scope of that Act and remain illegal. Therefore if wagering contracts were simply illegal at common law, the issue of enforceability is covered under the ICA.

There are six established heads of illegality at common law. ${ }^{55}$ They are:

(1) Contracts to commit a crime, a tort or a fraud on a third party;

(2) Contracts contrary to sexual morality;

(3) Contracts prejudicial to the public safety;

(4) Contracts interfering with the course of justice;

(5) Contracts injurious to good government;

(6) Contracts to defraud the revenue.

None of these categories applies to gaming contracts. There is no existing common law reason why gaming contracts should be illegal at common law.

\section{Void at common law}

When a contract is void, it simply cannot be enforced through the courts. The Law of Contract in New Zealand describes void contracts in this way: ${ }^{56}$

We may therefore conveniently attach the label contracts void at common law on grounds of public policy to three classes of agreement which the common law regarded as ineffective and on occasion described as 'illegal' contracts but which are inexpedient rather than unprincipled or manifestly improper. These are contracts: 
(1) to oust the jurisdiction of the courts;

(2) that tend to prejudice the status of marriage;

(3) in restraint of trade.

The Law of Contract in New Zealand also states the common law heads relating to void contracts are based on moral views of the community, as perceived by the courts. Even if there could be a public policy argument regarding the morality of such contracts, no existing common law head would convert those contracts to a void status. ${ }^{57}$ Yet Parliament does not view gambling as immoral. ${ }^{58}$ So the question arises: why has Parliament declared gaming contracts unenforceable?

\section{Void but not illegal by statute}

There are only three types of contracts which legislation makes void but not illegal: (i) wagering contracts, (ii) contracts in breach of the Credit Contracts Act 1981, and (iii) contracts in breach of the Commerce Act 1986. ${ }^{59}$

Contracts in breach of the two Acts are in restraint of trade or involving credit and are of a commercial nature. The status of contracts in breach of the Acts is focused on unfair trading and abuse of market position. Wagering contracts can also involve the giving of credit, and therefore raise the public policy concerns that people will bet using credit, lose, and owe a debt. Wagering contracts may also raise other issues under the Credit Contracts Act.

Yet gaming contracts, as a subset of wagering contracts, do not raise the concerns involving credit, nor the public policy concerns, if monetary consideration is used. This specific form of wagering should, therefore, have a different legal status.

IV DEPARTMENT OF INTERNAL AFFAIRS' 1995 REVIEW OF GAMING: NEW POLICY DIRECTIONS

\section{A Historical Public Policy: Morality Not at Issue}

Historically, gambling has been widespread in New Zealand. Yet between 1883 and 1900 there were fewer than 100 arrests for gambling and only half of those arrested were

57 If a new common law head could be argued on the basis of immorality, it could not apply effectively to matters of gambling. Parliament does not view gambling as immoral. See the later section of this paper, Part IV A.

58 For a historical reference, see David Grant On A Roll: A History of Gambling $\mathcal{E}$ Lotteries in New Zealand (Victoria University Press, Wellington, 1994) 57-58 [On a Roll].

59 The Law of Contract in New Zealand above n 7, 384-386. 
convicted. ${ }^{60}$ The foundation of New Zealand legislation has been a mix of attitudes towards both prohibition and regulation. Perhaps this duality is summed up best by the Honourable D A Highet who, when discussing the 1977 Gaming and Lotteries Bill, stated, "[a]lthough there are some who consider that all gambling is morally wrong ... most of us love a little flutter..."61

The shift towards more regulation than prohibition is summed up by John O'Sullivan and Paul Christoffel when commenting on gaming and public policy: "...the government was changing its emphasis from barring most gambling to controlling the destination of lottery profits." ${ }^{62}$ Thus there has been a marked change in Parliament's attitude whereby the duality of prohibition and regulation, as a means of control, has been altered to one of regulation only.

According to the Parliamentary Debates the reason gaming and wagering contracts under the GLA are unenforceable is that Parliament did not wish gambling debts to be enforceable against consumers. At the second reading of the Gaming and Lotteries Bill 1977, the Minister of Internal Affairs, the Honourable D A Highet stated that: "Part IX introduces a code of gaming law based on traditional attitudes that gaming debts should not be enforceable at law, which I feel is still the view of most New Zealanders." ${ }^{163}$

If this is the case, the enforceability of gaming contracts which use monetary consideration need not be excluded from enforcement. The Act clearly restricts an organisation from enforcing a gambling debt against a gaming consumer who bets on credit: section 128(1)(b). Yet such a blanket restriction on credit also takes away the rights of redress for the gaming consumer to ensure payment of winnings, even when that gaming consumer has paid monetary consideration. These are two distinct types of transactions. The right of redress for payment of winnings is based on a transaction where money is placed as a bet. Both parties are on an equal footing. The restriction against the giving of credit is based on public policy where one party has a distinct advantage over the other.

With the establishment of the TAB and the Lottery Grants Board the state has allowed for organised gaming, regulated by legislation. This regulation, rather than prohibition, is currently an accurate reflection of the attitudes of Parliamentarians. With the

60 On A Roll above n 58, 51.

61 (24 November 1977) 416 NZPD 4785.

62 "The Development of Gaming Policy in New Zealand" in Claudia Scott (ed) Lotteries, Gaming and Public Policy (Victoria University Press, Wellington, 1992) 62.

63 (24 November 1977) 416 NZPD 4788. 
establishment of commercial casinos, no doubt is left that Parliament has firmly established a consistent policy of regulation as opposed to a policy of prohibition or immorality. Commercial profit is allowed, and benefits from the taxes are gained.

Parliament's attitude towards gaming legislation has consistently been one of clarification and regulation. It has not addressed the morality issue behind gaming. The 1995 survey of public attitudes towards gambling addressed issues surrounding government control of gambling, but not the issue of whether the public perceived gambling as immoral. Therefore the question remains why gaming contracts are unenforceable when morality is not at issue.

\section{B Current Attitudes of the Public}

As part of the current review of gambling by the Department, a survey of the public was completed in 1995. Twelve hundred people were randomly selected to participate. Ninety percent of those surveyed had taken part in at least one gambling activity in the previous year. The average spent per year per capita on gambling was $\$ 413.00{ }^{64}$ Therefore, the vast majority of New Zealanders are potentially affected by the current legislative lack of redress.

The final results of the survey were compiled in People's Participation in and Attitudes Towards Gambling: Final Results of 1995 Survey. ${ }^{65}$ The focus of the survey was on the public's attitude towards government control. Among the questions asked were those such as: who can run such activities, where the activities are located, and what proportion of income should be returned in prizes. Other issues were whether there should be stricter control than that which already exists. Fifty-five percent said no. ${ }^{66}$ However when the respondents were asked: "In your opinion, do gaming activities need to be specially regulated by the Government, or should they be regulated in a similar manner to other businesses or forms of recreation?", sixty-three percent stated that they should be specially regulated. The two main reasons given for this were to prevent criminal activity $(19 \%)$ and to make sure profits fund worthy causes $(18 \%) .{ }^{67}$

64 Department of Internal Affairs Public Participation in and Attitudes Towards Gambling: Preliminary Results of the 1995 Survey (Wellington, May 1995) 1. See "Kiwis spent \$1 billion on gambling last year" The Dominion, Wellington, New Zealand, 12 April, 1999, 1.

65 Department of Internal Affairs (Wellington, March 1996).

66 Department of Internal Affairs People's Participation in and Attitudes Towards Gambling: Final Results of 1995 Survey (Wellington, March 1996) 79 [Final Results 1995 Survey].

67 See Final Results 1995 Survey above n 66, 82. 
The public attitude is that gambling should fund, as it has historically in New Zealand, worthy causes. A substantial majority did not approve of gaming as a business enterprise. ${ }^{68}$ However this view has been ignored by Parliament with the establishment of licensed casinos for commercial profit.

Another major concern pointed out by the survey was the effects of problem gambling and the responsibility of the government and those who operate the activities to act in a socially responsible manner. This issue was the reason behind the regulation of gambling historically.

Even though public opinion supports additional regulation, the enforceability at common law of gaming contracts is a separate issue. If the statutory bars to enforcement were removed the common law rights could exist alongside additional statutory obligations, as is the case with the Consumer Guarantees Act 1993 and the Fair Trading Act 1986. Common law enforceability would promote the Department's policy objectives.

\section{New Public Policy Directions}

On page iii of the paper Gaming - A New Direction for New Zealand the Department outlined its strategic priority area: ${ }^{69}$

To develop world-best-practice policy and industry structure models that maximise the gaming, racing and entertainment industries ability to contribute to economic and social growth and quality of life, while at the same time limiting any social and economic costs.

To achieve that policy, five overarching principles were listed: ${ }^{70}$

i Comparability of treatment, and regulatory neutrality both within the industry (between operators and different forms of gaming) and with other similar industries.

ii Consistency and predictability of the policy and regulatory regime including adequate consultation with affected parties when changes to the regime are considered.

iii Transparency of operation and regulation including:

Criteria for decision making that are easily understood and complied with and that incorporate appropriate rights of redress for operators with respect to regulatory decisions, and for participants with respect to operator behaviour.

68 Only 32\% were in favour: See Final Results 1995 Survey above n 66, 85.

69 Wellington, July 1996.

70 See Department of Internal Affairs Gaming -- A New Direction for New Zealand (Wellington, July 1996) 1. 
Ensuring that conflicts of interest, particularly in relation to Government's role, are avoided or made plain.

Reasonable access to information for participants in gaming activities.

iv Least cost intervention; any regulatory regime or other government intervention should be justified on a least cost basis such that the net benefits to the community as a whole are maximised.

v Consistency with the Treaty of Waitangi; any proposed policy must comply with the principles of the Treaty of Waitangi.

\section{Fairness}

Although fairness was not listed as an overarching principle, it is implicit when assessing the five overarching principles given.

Included in the Department's Synopsis of Submissions to the 1995 Review of Gaming Discussion Document ${ }^{71}$ were several submissions addressing the issue of fairness to both the players of the games and the providers of them. This issue was also addressed in the Department's publication Review of Gaming - A Discussion Document $1995^{72}$ which had a major heading entitled "Fairness to Participants". ${ }^{73}$ Under that heading several bullet points for discussion were listed. One those specifically addressed the issue of gaming consumers being paid their winnings: "that the prize will be paid out and that it will be worth what it is said to be worth."

On analysis of the intention as stated above with regard to payment, clearly in order to achieve fairness, clear and precise rights of redress are required.

\section{Rights of redress}

One of the five overarching principles to achieve that policy was "transparency of operation and regulation". Under that principle one of the three sub-principles was: ${ }^{74}$

Criteria for decision making that are easily understood and complied with and that incorporate appropriate rights of redress both for operators with respect to regulatory decisions, and for participants with respect to operator behaviour.

71 Wellington, August 1995.

72 Department of Internal Affairs Review of Gaming -- A Discussion Document 1995 (Wellington, August 1995).

73 Above $\mathrm{n} 72,30$

74 See above note 70,1 . 
To ensure that such transparency exists, the rights of redress for gaming consumers must be certain. Such certainty and transparency can easily be obtained by allowing gaming contracts to be enforceable at common law. Gaming contracts are enforceable with regard to licensed casinos, yet there are no identified public policy reasons why other gaming activities should have a different status.

\section{Comparability of treatment with other similar industries}

This overarching principle stresses the need to make gaming comparable to other industries. The public desire for additional regulation for the gaming industry should not be equated with specialised complicated rules. Rather, this points to the need for additional regulation that is straight-forward and easy for the average gaming consumer to understand before he or she enters into a transaction. Additional regulation is a separate issue from common law enforceability. Such additional measures can easily be consistent with common law enforceability. This would make the gaming industry's obligations consistent with those of other businesses. Certainty would be given to rights of redress for the gaming consumer.

\section{Enforceability as Supportive of New Policy Directions}

By removing the legislative restrictions regarding the enforceability of gaming contracts, the new policy directions of the Department would be assisted. At present gaming contracts are not enforceable at law. ${ }^{75}$ This inconsistency can only be viewed as unfair, because there are no reasons given to justify such an inconsistency. Further, fairness was addressed as an issue in several of the submissions to the Department. ${ }^{76}$ It clearly underlies the five overarching principles set out by the Department.

\section{CONCLUSION}

New policy directions aim to encourage rights of redress for the consumer. Currently there are situations where a gaming consumer has restricted or no rights of redress. As uncertainty currently exists, the Department should address this issue by repealing the restrictions on contractual enforceability. If gaming contracts were enforceable, the gaming consumer would have a straightforward right of redress.

75 See above $\mathrm{n} 4$.

76 Department of Internal Affairs Synopsis of Submissions to the 1995 Review of Gaming Discussion Document (Wellington, August 1995). 
